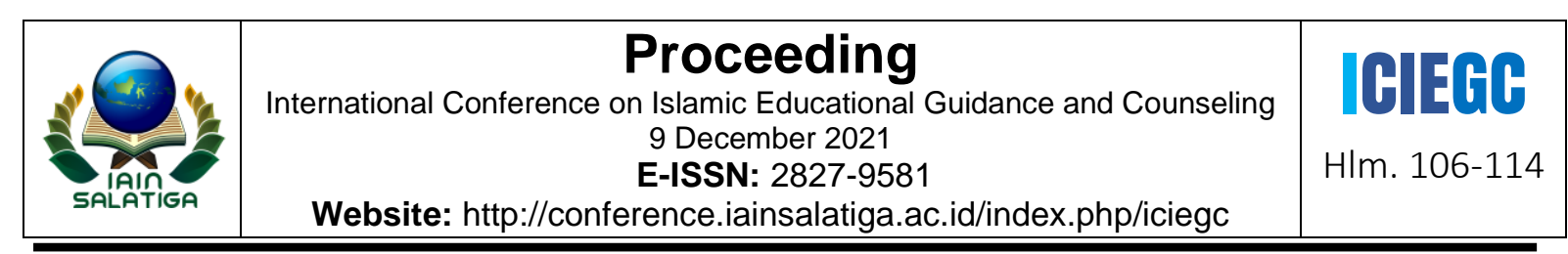

\title{
METAPHORICAL DEATH ACCEPTANCE (MDA) TECHNIQUE IN COUNSELING RELIGIOUS
}

\author{
Amirah Diniaty ${ }^{1}$, Anggi Farasagita Putri ${ }^{2}$ \\ 1,2 UIN Suska Riau
}

\begin{tabular}{|c|c|}
\hline Informasi Artikel & 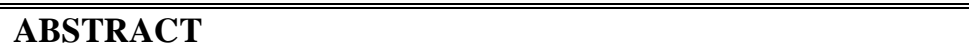 \\
\hline $\begin{array}{l}\text { Penulis Korespondensi: } \\
\text { Amirah Diniaty, } \\
\text { Email: Amirah.diniaty@uin- } \\
\text { suska.ac.id. }\end{array}$ & $\begin{array}{l}\text { The Metaphorical Death Acceptance (MDA) technique contains a } \\
\text { symbolic thought, the experience, a game of someone about } \\
\text { accepting the death process they will experience. It prepares the client } \\
\text { in a relaxed condition and then brought to the spiritual experience he } \\
\text { meets the angel of revocation to face his God. Conditions imagine } \\
\text { this process of death to be the starting point of change in the client } \\
\text { because the client is invited to think about whatever hopes, desires, } \\
\text { and final judgments of himself and others when he will die. The } \\
\text { researcher compiles this module from using action research. The } \\
\text { researcher used the MDA technique when carrying out the group and } \\
\text { individual counseling. The samples in this study were } 50 \text { students } \\
\text { and } 30 \text { housewives. The results of these techniques helped clients } \\
\text { perceive the problems they experience, instill their Islamic faith and } \\
\text { become missionary missions for counselors. This is one of counseling } \\
\text { religious for the client to get the meaning of life. }\end{array}$ \\
\hline
\end{tabular}

Keyword: The Metaphorical Death Acceptance (MDA) Technique; Counseling; Religious

\begin{abstract}
ABSTRAK
Teknik Metaphorical Death Acceptance (MDA) berisi pemikiran simbolis, pengalaman, permainan seseorang tentang menerima proses kematian yang akan dialaminya. Ini mempersiapkan klien dalam kondisi santai dan kemudian dibawa ke pengalaman spiritual ia bertemu malaikat pencabutan untuk menghadap Tuhannya. Kondisi membayangkan proses kematian ini menjadi titik awal perubahan pada diri klien karena klien diajak untuk memikirkan apa saja harapan, keinginan dan penilaian akhir dirinya dan orang lain ketika dia akan mati. Peneliti menyusun modul ini dengan menggunakan penelitian tindakan. Peneliti menggunakan teknik MDA saat melakukan konseling kelompok dan individu. Sampel dalam penelitian ini adalah 50 siswa dan 30 ibu rumah tangga. Hasil dari teknik ini membantu klien memahami masalah yang mereka alami, menanamkan iman Islam mereka dan menjadi misi misionaris bagi para konselor. Ini merupakan salah satu konseling religius bagi klien untuk mendapatkan makna hidup.
\end{abstract}

Kata kunci: Teknik konseling; Metaphora death acceptance; Religious 


\section{INTRODUCTION}

Every living creature will experience death (Al Quran: Ali Imran verse 185). As Muslims, we must believe in death as the end of sojourn in the world, to meet God. Prophet Muhammad even Muslims to always remember death and prepare to do good while living in this world.

Therefore, the meaning determines how a person lives his life. This study says that "death is a psychologically threatening event, but when people think, think, start looking for happiness" (Nathan DeWall and Roy Baumesiter, 2007). it is necessary to touch the meaning of death with touching and fun techniques Every living creature will experience death (Al Quran: Ali Imran verse 185). As Muslims, we must believe in death as the end of sojourn in the world, to meet God. Prophet Muhammad even Muslims to always remember death and prepare to do good while living in this world.

Therefore, the meaning determines how a person lives his life. This study says that "death is a psychologically threatening event, but when people think, think, start looking for happiness" (Nathan DeWall and Roy Baumesiter, 2007). For Muslim clients who experience problems and are discussed in counseling, it is necessary to touch the meaning of death with touching and fun techniques.

One technique for understanding the client's experience in a less threatening way is a metaphor (Babits; Shinerbourne and Smith, 2010 in Rahmadian, 2011). The Death Acceptance metaphor technique (abbreviated as MDA) contains a person's thoughts, experiences, symbolic games about accepting the process of death that he will experience. Counseling as a therapy containing the learning process needs to be built from the right mindset, packed feelings, conscious attitude, wise actions, and willingness to assume responsibility (Prayitno, 2015). The client who is prepared in a relaxed state is then brought on a spiritual experience that he meets the angel of death to face his Lord. The condition of imagining the process of death is the starting point for change in the client because the client is invited to think about what hopes, desires and endings are for himself and others when he will die.

\section{METHODE}

We used action research using The Kemmis model with steps; planning, action, observation, and reflection (Madya, 1994), to make a module MDA. The researchers designed a study to action (action research) the activity group counseling services. The 
samples in this study were 50 students and 30 housewives. The selection of an appropriate research object was made by random sampling.

We used individual and group counseling to try this technique. It was twice implemented in the dormitory, in a teaching class of counseling, and the mosque with 30 housewives. Group counseling has been done together with researchers and participants. The researcher as group leaders, and students as group members. It is conducted in four stages which include: the formation stage, intermediate stage, activities stage, and completion stage (Prayitno, 2004).

\section{RESULT AND DISCUSSION}

For group counseling, there were four stages to implement this technique. The first stage, the formation contains an introduction, self-involvement, self inclusion. The purpose of this stage is to understand the meaning and the members of the group's activities in the framework of group counseling, foster the growth of interest of members of the group atmosphere, growing to know each other, trust, accept and help among the members, the growth of a free and open atmosphere and the start of discussions about behavior and feelings within the group. Activities in the formation reveal the sense and purpose in the context of group counseling guidance and counseling services and explain how these principles of group activities, uncover and introduce themselves to each other, the icebreaker game/ iguanodons. In this case, the role of researchers, as well as group leaders, present themselves intact and open, warm, sincerely willing to help, and full of empathy.

Furthermore, the second stage is the intermediate stage as a bridge between the first stage with the third stage. The purpose of this stage is the member of free of feelings or reluctant, hesitant, shy, or do not trust to each other to continue the next stage, the increasingly consolidated group atmosphere, and togetherness, the interest to participate in group activities increased. The task of the researcher as a group leader in this stage describes the activities that will be pursued at a later stage, offer or observe whether the members are ready to undergo the next phase of activity, increase group participation. The group leader atmosphere encourages feelings, opens up as a self example, and is full of empathy.

The third phase of activities, aiming to discuss an issue or topic that is relevant to the lives of members in-depth. It would be related to the AEC's impact on their future. The use of a metaphor technique called "Death Acceptance" in this stage. There was three-stage for it. The leader made the clients more relaxing, by using simple relaxation therapy. 
After this stage, all participants must close their eyes up and listen to the leader's instruction about death acceptance. In the last stage, the participants told about their experience in the use of a metaphor technique called "Death Acceptance", and related it with their problems. The leader of the group acts as the traffic controller who is patient and open, active but less talk.

The next stage is the completion stage, namely assessment, and follow-up. At this stage of the unfolding of the impressions of the participants on the implementation of activities. The leader of the group still sought a warm atmosphere, free and open, providing a statement and saying thank you to participating members, encouraging further activities, a sense of friendship, and empathy.

In the action step of this research, group counseling was implemented in two and half hours. The group leader is the researcher as a counselor. In the opening step of the group counseling, self-introduction and group introduction takes place so that group members understand what group aims and benefits are. There was empathy, and the atmosphere was intimate because the earlier members of the group had known each other. The group leader asks the group members' commitment to be open to addressing personal issues that are perceived, voluntary or unenforceable and can maintain their confidentiality. The emphasis on confidentiality is made by uttering a joint promise to keep, maintain, keep all data and inappropriate and inappropriate information about the members of the group, to others outside the group. Furthermore, in the transition stage, the researchers deliver members to get ready to enter the activity.

The next stage of group counseling is to discuss the personal issues of group members in the activity phase. The students told about their problem. Not all the participants told about their problem. In the first group only six persons as volunteers. Four persons in the first group said that are no problem with themself that time.

Using the MDA technique for individual counseling, there were 5 stages.

1. Client acceptance and application of basic techniques

In this stage, the basic techniques described above are practiced by the counselor on the client until the problem is revealed and the counseling objectives are formulated to be more specific.

2. Counselor's explanation of MDA and Client's Agreement to carry it out 
Counselors need to explain the purpose of, and the process of implementing the MDA. Clients must be given the understanding to participate in the MDA voluntarily and focus on bringing about benefits.

\section{Relaxation}

The spiritual experience that the client will do must begin with relaxation first. Simple relaxation is done to prepare the client physically and psychologically, by asking the client to take a deep breath through the nose and exhale through the mouth until a relaxed condition is obtained and the muscles of the body relax. This relaxation is done repeatedly until the client feels completely relaxed and comfortable. To carry out this relaxation, the counselor must be able to adjust the intonation of the voice, creating a comfortable room atmosphere for the client. Clients are asked to close their eyes, focus, and concentrate on what the counselor is saying.

\section{Practice MDA}

The words spoken by the researcher in the metaphorical death acceptance technique are: "Imagine that you are calm, very calm. ...inhale deeply..through your nose, out through your mouth, feel your body in a relaxed state (spoken until all participants are relaxed and ready). Next, imagine that you are currently going with your family..there are your father and mother and brothers..to the beach..feel your feet on the white sand, small waves wet the tips of your toes...the wind is blowing gently. Inhale deeply through your nose...hold it...yes...let it out through your mouth. You stay calm, very calm. You are very relaxed and calm..now follow what I say.. in a very relaxed state...imagine that you are now, I take you to walk away from the beach, we walk towards a beautiful place....behind the beach... You see there is a beautiful garden filled with flowers... some are red, yellow, white... feel the fragrance of the flowers is very fragrant... In every corner of the garden there is a beautiful golden iron chair... sit on that chair.... take a breath through your nose and let it out through your mouth... get up from that beautiful chair, now pick the most beautiful flower, smell the sweet fragrance..and...look...now beside you, there is a big man who comes and talks to you. He conveyed the message that he would invite you to meet the Creator... The man took you away from the beautiful garden... into the sky. The whole family in the garden, saw your body lying stiffly asleep near the flower tree, they surrounded your body. Imagine...your physical body with your family, and your soul going with the Angel Azrael. Look...You see your family let 
you go. Listen to what they have to say about you (pause)... Ok, ....turns out your journey ends with the big man...He whispers to you that departure is delayed, you are brought back to your starting position...then I will end the metaphor this. I will ask you to open your eyes slowly on a count of three. One, two, three, yes please open your eyes.

The client then opens his eyes. The counselor allows the client to calm down and the conversation continues with a discussion.

\section{Discussion}

The counseling activity was continued with a discussion about the client's personal experience when visualizing MDA. The conversation is also related to the problems felt by the client and what he wants to change about himself to be better.

\section{Reinforcement}

The counselor's reinforcement to the client is added that a healthy Muslim person has faith in Allah SWT.

Counseling activities that have reached the final stage, contain the evaluation process and client contracts for further activities. Evaluation can then be interpreted as a process of collecting, analyzing, interpreting, and presenting the information obtained through measurement giving some meaning to the achievement of the results of an activity. The evaluation in counseling activities using the MDA technique is meant to be carried out by the counselor as follows:

1. Purpose of Evaluation

a. The counselor knows the change in understanding and the client's feelings about the problems he is experiencing in a positive direction

b. The picture shows that there is a change in the client's behavior in dealing with his problems, namely, he is more religious, his faith and gratitude for life increases

c. It is agreed between the counselor and the client that the activities carried out can be stopped and followed up for the next meeting.

\section{Evaluation Form}

Evaluation is carried out by the counselor by:

a. Oral; ask the client directly about the understanding, feelings, and changes that occur in him after the implementation of the MDA. This form of oral evaluation can be in the form of questions such as: 
- How do you feel now, after we discussed your problem and used the MDA technique?

- What changes did you feel?

b. Observation; observe changes that occur in clients from physical, facial expressions, and body language that shows positive changes such as; the client smiles shows he is happy, the client is silent without an expression meaning he is upset or disappointed. The termination of the counseling process is agreed upon by the client and counselor, and a contract for follow-up activities. When will the next counseling meeting be held, and the availability of the counselor? Thus the counseling process ends.

The Metaphorical Death Acceptance (MDA) technique contains a symbolic thought, the experience, a game of someone about accepting the death process. It prepares the client in a relaxed condition and then brought to the spiritual experience, he meets the angel of revocation to face his God. This process of death to be the starting point of change in the client because the client is invited to think about whatever hopes, desires, and final judgments of himself and others when he will die.

The contents of this module at the beginning are the introduction of basic counseling techniques ranging from attending, problem exploration, interpretation, and coaching. The second part of narrating the ways to do MDA techniques includes relaxation, MDA creative visualization, and dialogue of counselors and clients for discussion. The last section contains evaluation techniques for using techniques in counseling.

The results are the techniques used to help clients perceive the problems, instill their Islamic faith, and become missionary missions for counselors. There were many studies on risk behaviors of middle and high school Muslim students in Western Prevalence of Risk Behaviors among U.S. Muslim College Students 7 Europe (e.g., Amundsen, Rossow, \& Skurtveit, 2005), but nothing on college students.

Another research (Jayakody et al., 2011) gives the limited information that exists suggests that Muslim students report a low prevalence of most behaviors, with female Muslim students reporting even lower prevalence than male Muslim students. Results of research on premarital sexual behavior among students of one Islamic university in the city of Pekanbaru (Indonesia) showed that the respondents behave kissing, holding the sensitive part of the couple, hugging and anyone has sex relationships. It happens cause of peer pressure, exposure to pornographic media, and lifestyle (Diniaty, 2012). There was only one 
study, explored the protective influence of Islam on risk behavior in Western nations (Islam \& Johnson, 2003).

The teachings of Islam take reasonable steps to live in the world and the end of the so-called afterlife. The hard work of living in the world seems to live forever and do good for the afterlife as if every Muslim will die tomorrow (Hadist Muslim). Islam says that an individual after death continues. This means that every Muslim should strive to do the best and balanced for the world and the hereafter.

Tamimi and Tamimi (2014) argue in Islamic values, worldly life is a way surely, worldly life is a means to achieve life after death. In a divine worldview, real-life is the hereafter life and worldly life is a means or field that must plant in as much as possible to reap in the other world and reach the main goal. Imam Ali (AS) says in this regard (Surely the world is temporary abode and the Hereafter is the permanent abode, then you should take supply from road to your abode)

All human beings are mortal and hence death is an inevitable occurrence. Death has evolved into a very complex and dynamic system, involving biological, psychological, spiritual, societal, and cultural components (Kastenbaum, 2000). Whatever meanings we attach to death may have important implications for our wellbeing. Thus, at a personal level, attitudes toward death matter. Death defines the personal meaning and determines how we live (Neimeyer, 2005; Tomer, 2000; Tomer, Eliason, \& Wong, 2008). All human activities are framed by death anxiety and colored by our collective and individual efforts to resolve this inescapable and intractable existential given (Wong, 2011).

"Death acceptance" is a noble value that university students must be realized. Death acceptance research for the university student was in 2007, in University of Kentucky (Nathan DeWall and Roy Baumesiter, 2007). The researcher divided several dozen students into two groups. One group was told to think about a painful visit to the dentist while the other group was instructed to contemplate their death. Both groups were then asked to complete stem words, such as "jo_". The second group - the one that had been thinking about death - was far more likely to construct positive words, such as "joy". This led the researchers to conclude that "death is a psychologically threatening fact, but when people contemplate it, apparently the automatic system begins to search for happy thoughts".

\section{CONCLUSION}


Death acceptance research will be used in the metaphorical technique, associated with thoughts, experiences, symbolism in group counseling services. Working in a group is an activity in counseling that is often effective, to help individuals to solve personal and interpersonal problems. Integrative counseling blends various approaches and can be done using various properties as a metaphor of an idea or a problem (Ed, E. Jacobs, 2011).

\section{REFERENCES}

Amundsen, E. J., Rossow, I., \& Skurtveit, S. (2005). Drinking pattern among adolescents with immigrant and Norwegian backgrounds: A two-way influence? Addiction, 100(10), 1453-1463. http://dx.doi.org/10.1111/j.1360-0443.2005.01177.x.

Diniaty, A. (2012). Perilaku Seks Pranikah pada Mahasiswa. Jurnal Marwah, 11(2), 146161. http://ejournal.uin-suska.ac.id/index.php/marwah/article/view/505.

Ed.E. Jacobs., Robert. L.M., Riley L. Harvil. (2011). Group Counseling: A Strategies and Skill. America: Brooks/Cole.

Eric, W. (2015). Retrieved Nov 29, 2021, from BBC website: http://www.bbc.com/travel/story/ 20150408-Bhutan's-dark-secret-to-happiness.

Ghandour, L. A., Karam, E. G., \& Maalouf, W. E. (2009). Lifetime alcohol use, abuse, and dependence among university students in Lebanon: Exploring the role of religiosity in different religious faiths. Addiction, 104(6), 940-948. http://dx.doi.org/ 10.1111/j.1360-0443.2009.02575.x.

Gladding, S.T . (2012). Konseling Profesi Yang Menyeluruh. Jakarta: Indeks.

Islam, S. M. S., \& Johnson, C. A. (2003). Correlates of smoking behavior among Muslim Arab-American adolescents. Ethnicity \& Health, 8(4), 319-337. http://dx.doi.org/10.1080/ 13557850310001631722

Jayakody, A., Sinha, S., Tyler, K., Khadr, S. N., Clark, C., Klineberg, E., . . Viner, R.M., (2011). Early sexual risk among black and minority ethnicity teenagers: A mixedmethods study, Journal of Adolescent Health, 48(5), 499-506. http://dx.doi.org/10.1016/ j.jadohealth.2010.08.010

Kastenbaum, R. (2000). The psychology of death (3rd ed.). New York, NY: Springer.

Luczak, S. E., Corbett, K., Oh, C., Carr, L. G., \& Wall, T. L. (2003). Religious influences on heavy episodic drinking in Chinese-American and Korean-American college students. Journal of Studies on Alcohol, 64 (4), 467-471.

Luczak, S. E., Shea, S. H, Carr, L. G., Li, T. K., \& Wall, T. L. (2006). Binge drinking in Jewish and non-Jewish white college students. Alcoholism: Clinical and experimental research, 26(12), 1773-1778. http://dx.doi.org/10.1111/j.1530-0277.2002.tb02483.x

Mason, W. A, \& Windle, M. (2002). A longitudinal study of the effects of religiosity on adolescent alcohol use and alcohol-related problems. Journal of Adolescent Research, 17 (4), 346-363. http://dx.doi.org/10.1177/07458402017004002 